NBER WORKING PAPER SERIES

\title{
THE CAUSES AND CONSEQUENCES OF LAND USE REGULATION: EVIDENCE FROM GREATER BOSTON
}

\author{
Edward L. Glaeser \\ Bryce A. Ward \\ Working Paper 12601 \\ http://www.nber.org/papers/w12601
NATIONAL BUREAU OF ECONOMIC RESEARCH
1050 Massachusetts Avenue
Cambridge, MA 02138
October 2006

Glaeser thanks the Rappaport Institute for Greater Boston and the Taubman Center for State and Local Government for financial support. The data set was collected by the Pioneer Institute and we are particularly grateful to Amy Dain and Jenny Schuetz for their work on the data. This paper partially incorporates earlier work that was joint with Jenny Schuetz (Glaeser, Schuetz and Ward, 2006). David Luberoff provided significant assistance on this paper. The views expressed herein are those of the author(s) and do not necessarily reflect the views of the National Bureau of Economic Research.

(C) 2006 by Edward L. Glaeser and Bryce A. Ward. All rights reserved. Short sections of text, not to exceed two paragraphs, may be quoted without explicit permission provided that full credit, including (C) notice, is given to the source. 
The Causes and Consequences of Land Use Regulation: Evidence from Greater Boston Edward L. Glaeser and Bryce A. Ward

NBER Working Paper No. 12601

October 2006

JEL No. R14,R21,R31

\begin{abstract}
$\underline{\text { ABSTRACT }}$
Over the past 30 years, eastern Massachusetts has seen a remarkable combination of rising home prices and declining supply of new homes. The reductions in new supply don't appear to reflect a real lack of land, but instead reflect a response to man-made restrictions on development. In this paper, we examine the land-use regulations in greater Boston. There has been a large increase in the number of new regulations, which differ widely over space. Few variables, other than historical density and abundant recreational water, reliably predict these regulations. High lot sizes and other regulations are associated with less construction. The regulations boost prices by decreasing density, but density levels seem far too low to maximize total land value.
\end{abstract}

Edward L. Glaeser

Department of Economics

315A Littauer Center

Harvard University

Cambridge, MA 02138

and NBER

eglaeser@harvard.edu

Bryce A. Ward

NBER

1050 Massachusetts Ave

Cambridge MA 02138

bward@fas.harvard.edu 


\section{Introduction}

Over the past 25 years, many U.S. cities have experienced a remarkable combination of increases in housing prices and decreases in new construction (Glaeser, Gyourko and Saks, 2005). Boston is an extreme example of this phenomenon. Its prices have risen dramatically. Table 1 shows that based on Office of Federal Housing Enterprise Oversight (OFHEO) repeat sales indices, three of the four metropolitan subdivisions with the greatest price appreciation between 1980 and 2004 are in the Boston region (BostonQuincy, Cambridge-Newton and Suffolk). At the same time, as Figure 1 shows, the total number of permits issued in the Boston metropolitan area declined from 172,000 during the 1960 s to 141,000 during the 1980 s to 84,000 during the 1990 s.

The combination of rising prices and declining new supply suggests that Boston's high prices reflect more than just rising demand. After all, without increasingly inelastic supply, an increase in demand should lead to higher prices and more construction. One hypothesis is that supply has become increasingly inelastic in the Boston area because Greater Boston is running out of land. In Section II of this paper, we refute this hypothesis. Within the Boston region, higher densities are associated with more permitting, not less. Even if density did significantly decrease permitting, housing densities in greater Boston just have not changed enough to explain a significant downturn in permitting. We also follow Glaeser and Gyourko (2001) and show that the value of land in a hedonic regression is very low relative to the value of land when it sits below a new house, which suggests that there is no general shortage of land.

If increasing density levels cannot explain the decline in new construction, then one viable alternative hypothesis is that increasingly stringent land use regulations have made it more and more difficult for developers to build. To address this possibility, we turn to a new data set collected by the Pioneer Institute for Public Policy Research on land use regulations in greater Boston. The data set contains land use restrictions including lot size, wetlands regulations, septic rules and subdivision requirements, for 187 cities and 
towns within greater Boston. ${ }^{1}$ For many of the regulations, the data set also includes the dates when the regulations where imposed so that it is possible to look at changes over time.

In Section III of the paper, we establish three basic facts about land use regulation. First, along most dimensions there has been a dramatic increase in regulation since 1980. For example, the share of communities with rules restricting subdivisions has increased from less than 50 percent in 1975 to almost 100 percent today. Second, as Ellickson (1977) emphasized, there is a remarkable variety in the nature of these regulations; minimum lot sizes, subdivision rules, and septic and wetlands restrictions that go significantly beyond the state standards are only the most basic of regulations. Third, land use regulations are often astonishingly vague. For instance, several communities use variations of "an isolated depression ... that confines standing water" to define wetlands (Dain, 2006).

We then turn to the determinants of land use regulations. We do not know the dates that minimum lot sizes were established but all of them post-date 1915 and most of them post-date 1940. Therefore, we use city-level controls in 1915 and 1940 to try to explain minimum lot sizes. Like Evenson and Wheaton (2003), we find that historical housing density is the most important determinant of minimum lot size. Beyond that variable, more manufacturing and more minorities in 1940 are associated with smaller minimum lot sizes. Septic and wetlands regulations are associated with the amount of standing water, but it also appears that wetlands regulations after 1980 were used more aggressively in places that built more between 1971 and 1985, suggesting that these regulations may have been an attempt to reduce development.

In Section IV, we turn to the effects of these regulations. Unsurprisingly, we find a robust negative effect of minimum lot size on the amount of building in an area between 1980 and 2004 and on density today. These results are robust to controlling for a number of 1940 area characteristics and they are robust to using nineteenth century forest cover

\footnotetext{
${ }^{1}$ The database and a detailed discussion about how it was obtained is available at http://www.pioneerinstitute.org/municipalregs/index.asp.
} 
as an instrument for minimum lot size. As the average acre per lot increases by one, there is a $.4 \log$ point reduction in development between 1980 and 2002 . Other regulations also significantly reduce new construction. In a specification with town fixed effects, where we combine wetlands, septic and subdivision rules into a single index, we find that each extra rule reduces new construction by .1 log points.

In a housing price hedonic where we control for structural characteristics and lot size, we find that each acre per lot is associated with a 15 percent increase in housing prices. As economic theory predicts, this impact works through the average density in the community. When we control for density as well as lot size, the impact of minimum lot size disappears. The impact of other regulatory barriers on price is also positive. Each additional type of regulation (wetlands bylaws, septic rules, subdivision rules) raises housing prices by 7 percent, even controlling for housing density.

We end by asking whether restricting lot size maximizes the total value of land area in the community. In a simple model, reducing minimum lot sizes will increase total land value in a town if the share of housing prices associated with land is greater than the elasticity of price with respect to unit lot size minus the elasticity of price with respect to town density. We find that these two elasticities sum to approximately .1 while land's share of total value in the sample seems to be greater than .5. Together these results suggest that community densities are too low to be maximizing total land value.

\section{Is Lack of Land the Limit on Greater Boston's Housing Supply?}

In this section, we present evidence on whether the decline in permitting in greater Boston is the result of increasing land densities. Throughout this paper, we will use a sample of 187 cities and towns that lie between Route 495 and the city of Boston, excluding Boston itself. This sample includes all of the cities and towns that are physically closest to Boston except for those on Cape Cod. 
Our first, most obvious, piece of evidence is to examine the link within Boston between housing density in 1980 and new construction since then. Using data on permits from 1980 to 2002 and housing unit density in 1980 (based on the U.S. Census), Figure 2 shows the strong positive relationship between initial housing unit density and later construction; the places with the most land allow the least construction. This relationship might be explained by higher demand in high density areas, but as we will show in Section IV, prices are lower in less dense areas. As a result, controlling for price only increases the negative connection between land per house and new construction.

Lincoln, Weston and Concord are three contiguous towns that illustrate low levels of construction in land rich areas. Together, they have 12,889 homes and cover more than 39,000 acres. Yet despite being among the most expensive towns in the state, these areas together permitted just 1,746 new homes between 1980 and 2002. In our sample of 187 towns, there are another 22 localities with less than one home for every two acres that have allowed less than 30 units per year each since 1980.

A second piece of evidence, running counter to the view that greater Boston is running out of land, is that density levels have not increased very much over the past 25 years. For example, the total housing density in Suffolk County (which contains Boston) increased by 4.5 percent in the 1970s, 4.6 percent in the 1980s and 1.1 percent in the 1990s. Middlesex County (which contains Cambridge) grew more, but even its housing unit density increased by only 10.3 percent in the 1980s and by 6 percent in the 1990 s.

In a simple regression, where the dependent variable is the logarithm of the number of permits in a town in a year and where we control for town fixed effects and a dummy variable that takes on a value of one if the year is after 1990, the estimated coefficient on the dummy variable is -.267 . The standard error is .049. This means that in our sample, relative to the 1980 s, the number of new units declined by about $.27 \log$ points in the 1990s. 
Can controlling for increases in density drive this coefficient to zero and thereby explain the reduction in the number of new permits? If we simply control for housing density in the basic regression described above, the estimated decline in permitting becomes more severe, since density is positively predicted with new permits and density is rising. Using a national sample, Glaeser, Gyourko and Saks (2005) estimate a coefficient of -.1 on density, so a 10 percent increase in density is associated with a one percent decrease in permitting. If we fix the coefficient on density at -.1 , then the estimated dummy variable on the 1990s falls in absolute value to -.252 . If we fix the coefficient on density at -.25 , the estimated dummy variable on the 1990s is -.229. As such, even taking an extreme high estimate of the negative impact that density can have on construction, we estimate that rising density levels can only explain 14 percent of the decrease in eastern Massachusetts construction in the 1990s.

If land use restrictions didn't exist, then in equilibrium, land that extends a lot would be worth the same as land that sits under a new lot (Glaeser and Gyourko, 2003). A land shortage would mean that land value estimated in a hedonic regression is extremely high. Using data from Banker and Tradesman from 2000 to 2005, we estimate a standard hedonic regression with structural characteristics and find that an extra acre of land is associated with only an extra cost of only $\$ 16,000$. The average lot size in the sample is .7 acres and the average home sales price is $\$ 450,000$, so multiplying the hedonic price of land times the total acreage implies that land costs contribute only a small amount to the overall housing costs, even if our hedonic estimate is off by an order of magnitude. The natural explanation of this phenomenon is that the land market is not unrestricted and an acre of land is worth a great deal more if it sits under a new house than if it extends an existing lot.

A final piece of evidence on the land shortage hypothesis is that lot sizes for new homes in the Boston area rose from .76 in 1990 to .91 in 1998 (Jakabovics, 2006). Rising lot sizes are hard to reconcile with a land shortage. One explanation of this phenomenon is that incomes were rising, but Glaeser, Kahn and Rappaport (2000) estimate an income elasticity of demand for land among single-family homeowners of less than .2 and Boston 
area income rose by less than five percent. Those estimates predict a one percent increase in average lot size, not the 20 percent increase that is actually observed.

\section{Data Description and the Causes of Land Use Regulation}

The combination of increasing prices and decreasing construction can't be explained by a lack of land, but perhaps it can be explained by a man-made land shortage created by an increasingly stringent regulatory environment. To consider this possibility, we now turn to the Pioneer Institute's Housing Regulation Database for Massachusetts Municipalities in Greater Boston. This data was assembled by a team of researchers who interviewed local officials about the rules facing local developers. This data was supplemented with data from the MassGIS system which details for 1999-2000 the minimum lot size required throughout the state. ${ }^{2}$ Our permitting and demographic data come from the Census.

\section{Minimum Lot Sizes}

Before turning to the non-lot regulations, we will begin with the basic facts about lot size requirements in eastern Massachusetts. Lot sizes are not uniform within most towns; there are generally several different planning areas within a district. Since all of our other data is at the town level, we aggregate sub-areas with the formula:

(1) $\frac{\text { Acre }}{\text { Lot }}=\frac{\sum_{\text {Sub-areas }} \text { Acreage }}{\sum_{\text {Sub-areas }} \frac{\text { Acreage }}{\text { Minimum Lot Size }}}$

The numerator sums all of the land available for building in the town. The denominator sums the number of units that could be built in each sub-area based on existing minimum

\footnotetext{
2 This system was used and described more thoroughly by Evenson and Wheaton (2003).
} 
lot sizes, or $\frac{\text { Acreage }}{\text { Minimum Lot Size }}$. The total expression therefore divides total area by total units to get an average lot size for new units.

Figure 3 shows the distribution of this variable and the share of towns, share of people and share of land associated with different minimum lot sizes. Perhaps the most remarkable thing is the degree of heterogeneity across towns. One-fifth of the population and slightly under one-tenth of the towns have average lot sizes of 10,000 feet or less (one quarter acre), which is slightly under one-tenth of the towns that have average lot sizes of 70,000 feet or more. Unsurprisingly, people tend to live disproportionately in areas with denser zoning and land tends to be disproportionately allocated to less dense zoning. The model category in terms of both number of towns and amount of land is between 30,000 and 40,000 foot minimum lot size, which is about one acre, and which is also the average lot size of new homes found by Jacobovics (2006).

In Table 2, we show the distribution of town characteristics by minimum lot size broken into four categories. The towns with smaller minimum lot sizes are larger, more likely to be non-white and foreign born. The towns with larger lot sizes are further from Boston, and have higher housing prices (not controlling for anything). Income and education levels are mildly higher in the areas with high minimum lot sizes.

These correlations may be results of minimum lot size instead of causes of minimum lot size, so to investigate the cross-sectional determinants of restrictive zoning, we regress minimum lot size on characteristics of the town in 1915 and 1940. For most of these towns, the lot size regulations were put in place after World War II, so 1940 characteristics can be thought of as pre-zoning initial conditions. However, the initial wave of zoning occurred in the 1920s, so there is some possibility that those 1940 characteristics also reflect the influence of earlier zoning. To address this possibility, we also regress minimum lot size on 1915 characteristics. 
The results of these regressions are shown in Table 3. Missing data from the early censuses causes us to lose a small number of cities. The 1940 results are given in regression (1). The overwhelming determinant of current minimum lot size is the logarithm of housing density in 1940, which has a t-statistic above 12. As housing density increases by one $\log$ point (i.e. roughly doubles), minimum lot size falls by a quarter acre. On its own this variable can explain 68 percent of the variation in current minimum lot size. Regression (2) reproduces this finding using 1915 housing density. Again, the t-statistic is over 12 and the coefficient is quite comparable. The best way to understand the determinant of minimum lot size is that it is based on density levels immediately before entry into World War I.

Other town characteristics are also correlated with minimum lot sizes, but the effects are much weaker. For example, percent white in 1940 is associated with slightly more stringent minimum lot sizes. This result does not appear in 1915 because there is almost no variation in percent white during that year. The 1915 parallel is that towns with more immigrants have less stringent minimum lot sizes. These results present weak evidence for the view that high minimum lot sizes were used by white natives to restrict homes built for blacks and foreigners.

There is also a modest negative correlation between share of the population that works in manufacturing in 1940 and less restrictive minimum lot sizes. The same correlation appears in 1915, but the coefficient is statistically insignificant. There are two plausible explanations for this phenomenon. First, manufacturing may proxy for working class residents who were less concerned with restricting building for the poor. Second, manufacturing may proxy for the presence of businesses that have an interest in building more to keep housing prices low so that they don't need to pay workers more to compensate them for high housing costs.

It is also useful to note the variables that don't matter. For example, distance to Boston is irrelevant once we control for housing density. The share of homeowners in the town is actually associated with less restrictive zoning, but this effect is quite weak. 
The connection between historical density and minimum lot sizes prompted us to look for more ancient causes of minimum lot sizes. Using data from the Harvard Forest Survey of Massachusetts, we regressed minimum lot size today on the share of the town that was forested in 1885 . There is a 52 percent correlation between this variable and minimum lot size, which is shown in Figure 3. Forest cover in most of those towns in the $19^{\text {th }}$ century was determined by the value of agricultural land, so it reasonable to think that current zoning patterns reflect, in part, whether a town was worth clearing and settling based on the value of its pre-modern agricultural productivity.

\section{Other Land Use Restrictions}

While minimum lot size is the single most important land-use regulation, Massachusetts cities and towns have increasingly adopted other rules that also impact new construction. The bulk of these rules make new development more difficult, but some rules-like cluster zoning - can make it easier to build. The Pioneer Institute survey categorized all of these rules across the 187 cities and towns.

The three largest categories of added constraints on land use controls concern wetlands, septic systems and subdivision requirements. Both wetlands and septic systems are also regulated at the state level, so we are only considering additional requirements. At this point, a majority of towns have gone beyond the state standards. A smaller number of towns (54) have also instituted growth management policies that just act as a break on the amount of new development. Finally, a majority of towns have also introduced some form of cluster zoning that allows homes to be built on smaller lot sizes.

While it is easy to code whether a town has regulations of a particular type that go beyond state standards, there is remarkable heterogeneity across areas in the nature of these regulations. For example, the state Wetlands Protection Act protects all land within 100 feet of a wetland or floodplain, which includes all land that has 10,890 cubic feet of standing water at least once per year. Of the 131 communities that have imposed 
wetlands regulations that go beyond the state standard, 59 of them have introduced more stringent definitions of floodplains. Eleven of them, for example, have defined floodplains as including all areas that have 5,445 cubic feet of standing water. A number of them have gone to 1,000 cubic feet of standing water or less. 24 of these communities have adopted amorphous verbal definitions of floodplains, such as "an isolated depression ... that confines standing water" (Dain, 2006).

The range of rules that control septic systems is also remarkable. 109 towns go beyond the state's Title 5 septic rules. One particularly popular form of regulation is to require percolation rates below the state's maximum of 60 minutes per inch; 12 towns have imposed requirements of a maximum 20 minutes per inch percolation rate. Other septic rules increase the distance between septic systems and property lines, wetlands and wells. These regulations generally increase the amount of land needed to build. The diversity of these rules is shown in Figure 4 which shows the share of communities that have adopted different rules. While one might think that since septic rules are justified by public health concerns, there would be a relatively common standard throughout a small geographic area, the basic pattern is one in which different communities all adopt their own idiosyncratic permutations of the rules.

Subdivision requirements are similarly complex. All but six of our communities have adopted subdivision rules, and while some subdivision rules are more than 50 years old, amendments are frequent. The Pioneer database focused on subdivision rules concerning roads and sidewalks. One fifth of the sample required roads that were 32 feet or more. Some communities required roads that were 22 feet or less. There are also restrictions on sidewalks and curb materials.

Rules regarding lot shape also restrict subdivisions. Sometimes these rules are straightforward requirements that restrict the ratio of perimeter to area. In other cases the rules are more amorphous, such as Millbury's prohibition that "No pork chop, rattail, or excessively funnel-shaped or otherwise gerrymandered lots shall be allowed." 
There are three sets of policies that enable developers to avoid the minimum lot size regulations. First, a large number of communities have adopted cluster zoning that enables builders to use smaller lot sizes in exchange for setting aside some quantity of open space. In many cases, cluster zoning doesn't actually have a density bonus because the open space set aside must be enough so that the total density of the lot size still conforms to existing minimum lot size rules. Inclusionary zoning can enable developers to avoid minimum lot size requirements if they include enough affordable units. Towns have an incentive to build these affordable units because if they have too few units, developers can use the state rule, Chapter $40 \mathrm{~B}$, that allows them to ignore local zoning ordinances. Still, we have only found 21 towns where builders have taken advantage of inclusionary zoning rules. A third set of rules allow builders to develop at higher densities if the units are restricted to the elderly.

In our empirical work, we will use a simple categorical variable that takes on a value of one if the town has passed a rule that goes beyond the state standards regarding septic systems, wetlands and subdivisions. We will also sum those three categorical variables together for an overall regulatory barriers index (similar to Quigley and Raphael (2004)). While there is surely information lost in using such a coarse measure, the advantage of such coarseness is that it provides a simple measure with limited opportunities for data mining. This metric is an attempt to capture the overall regulatory environment in each community, while avoiding the loss of statistical clarity associated with trying to look at the effects of all three regulations simultaneously. As Pollakowski and Wachter (1990) argue, "land-use constraints collectively have larger effects than individually." Finally, we examine the impact of cluster and inclusionary zoning.

Figure 5 shows the adoption levels of the three forms of regulatory barriers and cluster zoning. All forms of regulation show a dramatic increase over time. The subdivision rules have now become ubiquitous. Figure 6 shows the share of communities that have amended their wetland, cluster and subdivision bylaws by year. There was a dramatic increase in the end of the 1990s. 
To fully capture the increase in the barriers to new construction, we must also consider the use of the court system. Lawsuits, particularly justified on environmental or nuisance grounds are also a perennial developer's complaint. Figure 7 shows the results of a Lexis/Nexis search of Massachusetts Court Decisions containing all of the keywords zoning, residential and either septic or wetland from 1964 to 2004. Again, there was a steady rise in the 1990s.

We now turn to the determinants of these land use regulations. Since subdivision requirements are so ubiquitous, we exclude those and focus on whether the town has wetlands rules, septic rules and cluster zoning. We include 1970 controls that predate these regulations. The results are shown in Table 4 which presents the marginal effects from probit regressions. While we have included a rich bevy of controls, almost none of these controls actually explain the adoption of these rules. This is not because we have included a large number of controls - almost nothing is consistently, significantly correlated with these outcomes when fewer controls are included either.

In the case of wetlands regulation, the variable that most reliably and significantly predicts wetlands rules is the amount of recreation water in the township. Places with more recreational water are unsurprisingly more dedicated to protecting wet spaces. They are also more likely to regulate septic systems more stringently. Septic rules are particularly associated with high levels of housing density, which seems quite reasonable, since the health costs of septic problems are greater in dense areas.

We were surprised that so few of the other variables were statistically significant. In the case of wetlands restrictions, there is a significant negative relationship between the amount new development in the 70s and early 80 s and adoption and a marginally significant positive relationship between adoption and the share of the population with 16 years or more of schooling. More generally, these regulations which vary so much from town to town, are surprisingly uncorrelated with most town characteristics. This may either reflect an efficiency view of these regulations where they are being tied to unmeasured land characteristics or the view that these regulations are fairly random. 
In the third regression, we look at the correlates of cluster zoning. In this case, bigger and denser towns are much more likely to have cluster zoning, presumably because those residents are less troubled by the occasional denser development. There is also a weak correlation with education levels which may reflect the fact that "Smart Growth" has become popular among environmentally oriented educated elites.

\section{The Consequences of Land Use Regulation}

We now turn to the consequences of land use regulation. We first look at permitting and density. We begin with minimum lot size and then turn to the other regulations.

In the case of minimum lot size, we can only look at the cross section of towns, since we do not know when these rules were adopted. We include a bevy of 1940 era controls including town area and housing, which are equivalent given our logarithmic specification to controlling for density, distance to Boston, share of the population younger than 18, share foreign born and percent white. We also include a dummy variable for whether the town has a major university defined as being among the top 50 universities or top 25 colleges in the 2005 U.S. News and World Report rankings. We stick to controls from the earlier era because of the possibility that later control variables might themselves reflect the influence of minimum lot size requirements.

The first three regressions look at results single family permits for 1980-2002 and for the 1980s and 1990s separately. The coefficient for the whole period is .-547 which has a tstatistic of 4.1. The coefficient in the $1980 \mathrm{~s}$ is -.509 and the coefficient in the $1990 \mathrm{~s}$ is .685. These coefficients should be interpreted as suggesting that as the town increases the average lot size needed to build by one acre, the number of new permits declines by $.5 \log$ points or about 50 percent. The coefficient does rise between the 1980s and 1990s, suggesting an increasing tendency of these rules to block new construction, but the change is not itself statistically significant. 
The only control variable that reliably predicts more construction is town area. Bigger towns have more permits, but this is unsurprising since our permit measure reflects overall permits, not permits per acre. The coefficient on town area is close to one which suggests that the basic ratio of new units per acre is constant with respect to town size. Major universities are negatively correlated with development in the 1990s, but not before then. Percent white is positively correlated with development in the 1990s.

In the fourth regression, we use 1980 controls rather than 1940 controls and look at development for the entire time period. The coefficient on acre per lot drops to -.415 but remains statistically significant. Housing density now becomes significant and the share of young people also predicts growth.

The fifth regression uses 1940 controls for total permits, single family and multi family. In this case, the coefficient becomes -.442 which remains significant. More 1940 era characteristics are significant such as share that is foreign born in this case because they do predict multi-family development more than single-family development.

In the final regression of this table, we look at the impact of minimum lot size on total housing supply in 2000. In this case the coefficient is -.337 which has a t-statistic of 3.69. Other variables like housing stock in 1940 and share that is foreign born are also strongly correlated with the outcome variable. Distance to Boston also predicts density as we would expect from the monocentric model. Perhaps unsurprisingly, minimum lot size does predict less housing.

We now turn to the effects of other regulations. Since we know when these regulations were imposed and since we have permits by year, we are now able to run panel regressions both with and without town fixed effects. When we exclude town fixed effects we include 1970-era controls, as we did in the regression explaining these variables, including town area, housing stock, share of the population below age 18, share of the population that is white and share of the population with college degrees. We also 
include the dummy variable indicating the presence of a major university. All standard errors are clusters by town.

The first two regressions show the three types of rules included simultaneously. In the specification with town controls, wetlands and subdivision rules are negatively but insignificantly correlated with development. Septic rules are extremely weakly positively associated with development. In the specification with town fixed effects, all three coefficients negatively predict development, but only the subdivision rules are statistically significant.

In regressions (3) and (4), we aggregate these variables into an index by just adding them together. In the specification without fixed effects, the coefficient is -.057, which is statistically insignificant. In the specification with town fixed effects, the coefficient rises to -.105 which has a t-statistic of two. This specification suggests that each new regulation is associated with about a ten percent reduction in new construction. Of course, we cannot be sure that these restrictions are actually causing the reduction in new construction. The decline in new construction might reflect a general anti-growth atmosphere that reflects itself in both new regulations and a reduction in permits.

The estimated coefficient of -.1 suggests new construction falls by about ten percent with each new regulation. We think this estimated effect is fairly large. However, since the variation in new permitting is also quite large, the estimate remains imprecise. This variation helps us to understand why using annual permit data to estimate regulation effects will always be difficult.

In regressions (5) and (6) we add cluster and inclusionary zoning, both with and without town fixed effects. In the first specification, both coefficients are positive and cluster zoning is statistically significant. In town fixed effect specification, neither coefficient is statistically significant. Cluster zoning still has a sizable coefficient that is just imprecisely measured. We take this as suggestive evidence supporting the view that these rules may be having a positive effect on construction. 
Price Effects

In Table 4, we turn to the correlation between lot size and sales prices. We use Banker and Tradesman data on housing price transactions between 2000 and 2005. Our basic regression is:

(2) $\log ($ Sales

$$
\text { Price })=\alpha \bullet \frac{\text { Acre }}{\text { Lot }}+\text { House Characteristics }+ \text { Town Characteristics }
$$

Our home characteristics include the year of construction, total number of room, interior square footage and lot size. Our town characteristics include the set of 1940 characteristics used in the other regressions.

In the first regression, the coefficient on acres per lot is 0.156 . This coefficient means that each extra acre per lot is associated with a 15.6 percent increase in the value of a house. This supports the view that minimum lot size rules do increase value for existing homeowners. In the second regression, we include our control for the 1940 housing stock and this coefficient flips sign and becomes statistically insignificant. This change reflects the fact that there is no effect of minimum lot size beyond its correlation with local density.

These results should not surprise us. These towns are all part of one housing market, and standard urban theory tells us that there should be no effect on the town's prices, relative to other towns in the same market, once the characteristics of the town have been controlled. $^{3}$ A reasonable analogy is the impact of OPEC quantity restrictions on the price of Saudi and U.S. crude oil. If OPEC restricts quantities, then this will raise the price for all oil, but since Saudi and U.S. crude are identical, there should be no impact on the price difference between these commodities. In the same sense, housing in

\footnotetext{
${ }^{3}$ Katz and Rosen's (1987) examination of the price effects of growth controls compares much larger areas. Maser, Riker and Rossett (1977) look at smaller areas, but they are focused on type of use zoning, not restrictions on density, and they do not try to estimate a zoning effect separate from the uses in the area.
} 
Wellesley and Weston (two towns in our sample) are close substitutes. If Weston restricts housing supply, this will push up prices in the entire sample, but it will not increase the prices of Weston homes relative to Wellesley homes once we have controlled for density.

In regression (3), we include the control for regulatory barriers. Our regulatory barriers index is significant and positively correlated with housing prices. The coefficient of .101 suggests that each extra regulation is associated with a 10 percent increase in prices. Again, this result gets weaker when we control for density, but it remains statistically significant.

\section{Land Value Maximization}

While the previous regressions suggest that reducing densities through land use regulation increases the value of homes in the area, this does not mean that the total land value in the area has been maximized (Brueckner, 1990). Since we do not observe land values, we can instead turn to the total value of housing which equals Land*Housing Density*House Price. The total land available in the town is a constant and can be ignored, so the question is whether decreases in density increase the product of density times housing price.

We let $H\left(A, N / A_{T}\right)$ denote the price of a house which depends both on its lot size (denoted A) and the total density in the town, which equals the number of homes $(\mathrm{N})$ divided by the total land area of the town (denoted $A_{T}$ ). The total land value in the town equals $N\left(H\left(A, N / A_{T}\right)-C\right)$ where $\mathrm{C}$ is the cost of constructing each house. If each house is identical and built on the town's minimum lot size, denoted $\underline{A}$ ), then total land value can be written $\left(A_{T} / \underline{A}\right)(H(\underline{A}, 1 / \underline{A})-C)$. The derivative of total land value with

respect to minimum lot is $\left(A_{T} / \underline{A}^{2}\right)\left(\underline{A}, H_{1}(\underline{A}, 1 / \underline{A})-\underline{A}^{-1} H_{2}(\underline{A}, 1 / \underline{A})-H(\underline{A}, 1 / \underline{A})+C\right)$. This is negative if 
(3) $\frac{H(\underline{A}, 1 / \underline{A})-C}{H(\underline{A}, 1 / \underline{A})}>\frac{\underline{A}, H_{1}(\underline{A}, 1 / \underline{A})}{H(\underline{A}, 1 / \underline{A})}-\frac{H_{2}(\underline{A}, 1 / \underline{A})}{\underline{A}, H(\underline{A}, 1 / \underline{A})}$,

or the share of housing prices not associated with construction costs is greater than the elasticity of housing prices with respect to lot size minus the elasticity of housing prices with respect to community density. If we let $\mathrm{D}$ denote density in the community, so that housing prices are denoted $\mathrm{H}(1 / \mathrm{D}, \mathrm{D})$ then

(4) $\frac{D}{H} \frac{d H(1 / D \cdot D)}{d D}=-\frac{H_{1}(1 / D \cdot D)}{D H(1 / D \cdot D)}+\frac{D H_{2}(1 / D \cdot D)}{H(1 / D \cdot D)}=-\frac{\underline{A}, H_{1}(\underline{A}, 1 / \underline{A})}{H(\underline{A}, 1 / \underline{A})}+\frac{H_{2}(\underline{A}, 1 / \underline{A})}{\underline{A}, H(\underline{A}, 1 / \underline{A})}$.

Condition (3) also implies that the share of housing prices associated with "land value" is greater than the -1 times the total elasticity of housing prices with respect to total area density, not controlling for individual lot size.

In Table 8, we look at the relationship between housing prices and area density controlling for housing characteristics. We include the basic town controls, like distance to Boston and the presence of a major university, but not the controls for demographic variables that will reflect zoning decisions. In the first regression, we see that the lot size coefficient is .06 and the town density coefficient is -.083 . Together these suggest an overall density coefficient of -.143 .

These results are compromised since density levels may be driven by omitted housing characteristics that increase demand. Larger lot sizes may be results from cheaper prices. This concern means that standard hedonic regressions may understate the true negative impact of density on housing prices. To address this concern, we use instruments for current density level. In regression (2), we use our minimum lot size variable to instrument for the towns' average density level. In regression (3), we use the forest cover of the town in 1885 to instrument for town density, and in regression (4) we use the log of town density in 1915. In regressions (5) and (6), we exclude the control for the individual houses lot size. In these specifications, the coefficient on the town's average 
density reflects the full effect of density on housing prices. Regression (6) again uses the $\log$ of density in 1915 as an instrument.

In regressions (2) - (4), the density and lot size parameters shift a bit, but the combined density effect remains quite small. The combined effects range from -..072 to -.164. In regressions (5) and (6), we estimate a town density effect not controlling for individual lot size. Again, the elasticity ranges from -.11 to -.14. These elasticity estimates must be compared with land's share in the value of homes.

In 2004, in our sample, the average home cost $\$ 450,000$ and had 1800 square feet of interior space. Using R.S. Means data on construction costs, Gyourko and Saiz (2004) estimate a 97 dollar per square foot cost of new construction for the Boston area. These figures suggest that the physical structure in the average home costs 174,600 dollars and that land's share in value is 61 percent. While we cannot be confident that this number is exactly correct, the wide gap between 61 percent and our estimated density effects strongly suggests that reducing minimum lot sizes would increase total land values.

There are at least two plausible reasons why these towns do not seem to be maximizing land values. Perhaps current densities are based on historical conditions that don't reflect current demand. A second explanation is that zoning decisions are made without the possibility of transfers between builders and current owners. ${ }^{4}$ The absence of these transfers, which are essentially illegal in Massachusetts, makes it difficult for existing homeowners to reap many benefits from new development.

\section{Conclusion}

Over the last 25 years, greater Boston has seen a remarkable increase in housing prices and a decline in the number of new units. This change reflects increasingly restricted supply. The reduction in supply doesn't reflect an exogenous lack of land. There has been no significant increase in density levels associated with declining construction.

\footnotetext{
${ }^{4}$ Fischel (1978) is the classic analysis of the property rights issues surrounding land use controls.
} 
Development is greater in dense places. Lot sizes are increasing, not falling. The value of land when it extends an existing lot is not great. Instead, the decline in new construction and associated increase in price reflects increasing man-made barriers to new construction.

In this paper, we catalog the barriers to new construction. Minimum lot size is the most important of these barriers, but wetlands regulations and septic rules have also become increasingly tough. All barriers have all increased over time, but our ability to explain where they have been adopted is quite limited. The two most important explanatory variables are early twentieth century density patterns which correlate well with current minimum lot sizes and the presence of recreational water which explains water-related rules.

The impact of lot size on new development is quite clear. Each extra acre per lot is associated with about 50 percent fewer permits between 1980 and 2002. The impact of other controls on construction is weaker, but each extra rule appears to reduce new construction by about 10 percent when we control for town specific fixed effects. Minimum lot size is associated with higher prices, but as urban theory predicts, this effect works by reducing density levels. Each extra regulation also appears to increase price by $.07 \log$ points.

While regulations appear to increase prices, reductions in density in our sample are associated with reductions in the total land value in a town. This finding suggests that these towns are being too restrictive relative to land value maximization. Understanding the failure to maximize land value is a good topic for future research. 


\section{References}

Brueckner, Jan K (1990). "Growth Controls and Land Values in an Open City", Land Economics, Vol. 66, No. 3: 237-248.

Dain, Amy (2006). "Reference Guide to Residential Land-Use Regulation in Eastern Massachusetts: A study of 187 communities", Cambridge: Rappaport Institute for Greater Boston, Harvard University and Boston: Pioneer Institute for Public Policy Research.

Ellickson, Robert C. (1977) "Suburban Growth Controls: An Economic and Legal Analysis" Yale Law Journal 86(3): 385-511.

Evenson, Bengate and William C. Wheaton (2003). "Local Variation in Land Use Regulation”, Brookings-Wharton Papers on Urban Affairs, 221-260.

Fischel, William A. (1978) “A Property Rights Approach to Municipal Zoning” Land Economics 54(1): 64-81.

Glaeser, E. and J. Gyourko (2003) "The Impact of Building Restrictions on Housing Affordability," Federal Reserve Bank of New York Economic Policy Review 9(2):2139.

Glaeser, E., Gyourko, J., and R. Saks (2005) "Why Have Housing Prices Gone Up?” American Economic Review Papers and Proceedings 95(2): 329-333.

Glaeser, Edward L., Matthew Kahn, and Jordan Rappaport (2000). "Why Do the Poor Live in Cities", NBER Working Paper 7636.

Glaeser, E., Schuetz, J. and B. Ward (2006) "Regulation and the Rise of Housing Prices in Greater Boston,” Rappaport Institute - Pioneer Institute Working Paper.

Gyourko, J. and A. Saiz (2004) "Reinvestment in the Housing Stock: The Role of Construction Costs and the Supply Side" Journal of Urban Economics 55(2): 238256.

Katz, L. and K.T. Rosen (1987) "The Interjursdictional Effects of Growth Controls on Housing Prices," Journal of Law and Economics 30(1): 149-160.

Jakabovics, A. (2006) "Housing Affordability Initiative: Land Use Research Findings" http://web.mit.edu/cre/research/hai/land-use.html

Maser, Steven, Riker, William and Richard Rosett (1977) "The Effects of Zoning and Externalities on the Price of Land: An Empirical Analysis of Monroe County, New York" Journal of Law and Economics 20(1): 111-132. 
Pollakowski, H.O. and S.M. Wachter (1990) "The Effects of Land-Use Constraints on Housing Prices," Land Economics 66(3): 315-324.

Quigley, John M. and Steven Raphael (2004). "Regulation and the High Cost of Housing in California.” Berkeley Program on Housing and Urban Policy Working Paper W04-008. 
Table 1 - Percent Change in Housing Prices, 1980-2004, Top 20 Metropolitan Areas

\begin{tabular}{|c|c|}
\hline Metropolitan Area & $\begin{array}{c}\text { Percent Change in } \\
\text { OFHEO Repeat Sales } \\
\text { Index, 1980-2004 }\end{array}$ \\
\hline Nassau-Suffolk, NY Metropolitan Division & $251 \%$ \\
\hline Boston-Quincy, MA Metropolitan Division & $210 \%$ \\
\hline Cambridge-Newton-Framingham, MA Metropolitan Division & $180 \%$ \\
\hline Essex County, MA Metropolitan Division & $179 \%$ \\
\hline Salinas, CA Metropolitan Statistical Area & $162 \%$ \\
\hline New York-Wayne-White Plains, NY-NJ Metropolitan Division & $158 \%$ \\
\hline Napa, CA Metropolitan Statistical Area & $156 \%$ \\
\hline Santa Cruz-Watsonville, CA Metropolitan Statistical Area & $156 \%$ \\
\hline Worcester, MA Metropolitan Statistical Area & $149 \%$ \\
\hline San Luis Obispo-Paso Robles, CA Metropolitan Statistical Area & $146 \%$ \\
\hline San Francisco-San Mateo-Redwood City, CA Metropolitan Division & $138 \%$ \\
\hline San Jose-Sunnyvale-Santa Clara, CA Metropolitan Statistical Area & $137 \%$ \\
\hline Santa Rosa-Petaluma, CA Metropolitan Statistical Area & $131 \%$ \\
\hline Santa Barbara-Santa Maria-Goleta, CA Metropolitan Statistical Area & $129 \%$ \\
\hline Providence-New Bedford-Fall River, RI-MA Metropolitan Statistical & $129 \%$ \\
\hline Oakland-Fremont-Hayward, CA Metropolitan Division & $116 \%$ \\
\hline Edison, NJ Metropolitan Division & $114 \%$ \\
\hline Newark-Union, NJ-PA Metropolitan Division & $112 \%$ \\
\hline Oxnard-Thousand Oaks-Ventura, CA Metropolitan Statist & $109 \%$ \\
\hline San Diego-Carlsbad-San Marcos, CA Metropolitan Statistical Area & $109 \%$ \\
\hline
\end{tabular}

Source: OFHEO repeat sales index, raw index is adjusted for inflation using CPI minus shelter 
Table 2 -- Characteristics of municipalities, by average SF minimum lot size

\begin{tabular}{|l|cccc|}
\hline & $(1)$ & $(2)$ & $(3)$ & $(4)$ \\
\cline { 2 - 5 } & $<20,000$ & $20-35,000$ & $35-50,000$ & $50,000+$ \\
\hline \hline Share of regional pop & 42.7 & 21.7 & 21.3 & 14.3 \\
Share of regional land & 12.7 & 18.9 & 28.8 & 39.6 \\
Number of towns & 42 & 38 & 51 & 55 \\
Mean population & 41,338 & 23,218 & 16,987 & 10,571 \\
& $(32,007)$ & $(17,385)$ & $(12,477)$ & $(7,851)$ \\
Pct white & 84.5 & 92.1 & 93.7 & 94.5 \\
& $(15.1)$ & $(7.9)$ & $(3.8)$ & $(4.1)$ \\
Pct foreign-born & 13.9 & 7.2 & 6.2 & 5.3 \\
& $(8.5)$ & $(4.9)$ & $(2.9)$ & $(3.2)$ \\
Pct w/ BA+ & 37.3 & 35.2 & 38.8 & 43.1 \\
& $(17.6)$ & $(13.6)$ & $(14.6)$ & $(19.2)$ \\
Distance to Boston (miles) & 14 & 22 & 24 & 28 \\
& $(10)$ & $(8)$ & $(8)$ & $(8)$ \\
Land area (acres) & 6,551 & 10,829 & 12,254 & 15,642 \\
& $(5,240)$ & $(4,651)$ & $(5,218)$ & $(9,742)$ \\
Pct housing in SF & 49.6 & 68.3 & 73.5 & 79 \\
& $(21.9)$ & $(16.5)$ & $(12.4)$ & $(13.5)$ \\
Mean hsg price & 238,160 & 217,818 & 229,635 & 265,444 \\
& $(91,766)$ & $(73,394)$ & $(74,562)$ & $(124,045)$ \\
Mean rent & 829 & 732 & 714 & 773 \\
& $(159)$ & $(166)$ & $(121)$ & $(202)$ \\
\hline
\end{tabular}

Notes: standard deviations in parentheses, top rows show means

Source: 2000 census, Mass GIS 
Table 3 - 1940, 1915 Determinants of Average Minimum Lot Size

\begin{tabular}{|l|cc|}
\hline \multirow{2}{*}{$\ln$} & $(1)$ & $(2)$ \\
\cline { 2 - 3 } & $\begin{array}{c}\text { Avg. Min. Lot } \\
\text { Size }\end{array}$ & $\begin{array}{c}\text { Avg. Min. Lot } \\
\text { Size }\end{array}$ \\
\hline ln(Tousing Density) & 0.011 & 0.017 \\
Distance to Boston & $(0.034)$ & $(0.041)$ \\
& -0.268 & -0.241 \\
Pct. Manufacturing & $(0.021)^{* * *}$ & $(0.028)^{* * *}$ \\
& -0.003 & 0.003 \\
Pct. White & $(0.002)$ & $(0.003)$ \\
& -0.192 & -0.07 \\
Pct. Foreign Born & $(0.069)^{* * *}$ & $(0.146)$ \\
& 0.009 & -0.013 \\
Pct. Owner Occupied & $(0.005)^{*}$ & $(0.007)^{*}$ \\
& -0.005 & -0.006 \\
Constant & $(0.004)$ & $(0.003)^{*}$ \\
& -0.006 & \\
\hline Control Data Year & $(0.002)^{* * *}$ & \\
\hline Observations & -0.175 & 3.041 \\
R-squared & $(0.566)$ & $(0.812)^{* * *}$ \\
\hline Robust standard errors in parentheses & 1915 \\
* significant at 10\%; $* *$ significant at 5\%; *** significant at $1 \%$ \\
\hline
\end{tabular}


Table 4 -- 1970 Determinants of Wetbylaws, Septic Rules, and Cluster Zoning

\begin{tabular}{|c|c|c|c|}
\hline & (1) & (2) & (3) \\
\hline & $\begin{array}{c}\text { Has } \\
\text { wetlands } \\
\text { bylaw }\end{array}$ & $\begin{array}{l}\text { Has septic } \\
\text { rules }\end{array}$ & $\begin{array}{l}\text { Has cluster } \\
\text { provisions }\end{array}$ \\
\hline In(housing stock) & $\begin{array}{l}0.037 \\
(0.055)\end{array}$ & $\begin{array}{c}-0.385 \\
(0.085)^{\star \star \star}\end{array}$ & $\begin{array}{c}0.126 \\
(0.047)^{\star * \star}\end{array}$ \\
\hline In(town area) & $\begin{array}{l}-0.096 \\
(0.118)\end{array}$ & $\begin{array}{c}0.204 \\
(0.181)\end{array}$ & $\begin{array}{c}0.054 \\
(0.095)\end{array}$ \\
\hline Distance to Boston & $\begin{array}{l}-0.002 \\
(0.005)\end{array}$ & $\begin{array}{l}-0.009 \\
(0.007)\end{array}$ & $\begin{array}{l}0.003 \\
(0.004)\end{array}$ \\
\hline Pct non-Hispanic white & $\begin{array}{c}0.007 \\
(0.023)\end{array}$ & $\begin{array}{l}-0.048 \\
(0.047)\end{array}$ & $\begin{array}{l}-0.009 \\
(0.019)\end{array}$ \\
\hline Pct foreign born & $\begin{array}{l}-0.028 \\
(0.018)\end{array}$ & $\begin{array}{l}-0.02 \\
(0.027)\end{array}$ & $\begin{array}{l}-0.012 \\
(0.015)\end{array}$ \\
\hline Pct owner-occupied & $\begin{array}{l}-0.002 \\
(0.004)\end{array}$ & $\begin{array}{l}-0.004 \\
(0.006)\end{array}$ & $\begin{array}{l}-0.002 \\
(0.003)\end{array}$ \\
\hline Pct BA, post-grad & $\begin{array}{c}0.008 \\
(0.004)^{\star}\end{array}$ & $\begin{array}{c}0.005 \\
(0.005)\end{array}$ & $\begin{array}{c}0.008 \\
(0.003)^{* *}\end{array}$ \\
\hline In(acres water based recreation +1$)$ & $\begin{array}{c}0.062 \\
(0.025)^{\star *}\end{array}$ & $\begin{array}{c}0.087 \\
(0.034)^{\star *}\end{array}$ & $\begin{array}{l}-0.013 \\
(0.020)\end{array}$ \\
\hline In(acres water + wetlands +1$)$ & $\begin{array}{c}0.041 \\
(0.055)\end{array}$ & $\begin{array}{c}0.164 \\
(0.082)^{* *}\end{array}$ & $\begin{array}{c}0.049 \\
(0.047)\end{array}$ \\
\hline $\begin{array}{l}\text { In(acres of new development 1971- } \\
1985+1)\end{array}$ & $\begin{array}{c}0.11 \\
(0.052)^{\star *}\end{array}$ & $\begin{array}{l}0.096 \\
(0.085)\end{array}$ & $\begin{array}{c}0.02 \\
(0.039)\end{array}$ \\
\hline Observations & 186 & 186 & 186 \\
\hline
\end{tabular}


Table 5 - Effect of Minimum Lot Size on Permits and Housing Stock, 1980-2002

\begin{tabular}{|c|c|c|c|c|c|c|}
\hline & (1) & $(2)$ & (3) & (4) & \multirow{3}{*}{\begin{tabular}{|c|}
$(5)$ \\
$\ln$ (total permits) \\
$1980-2002$ \\
\end{tabular}} & \multirow{3}{*}{\begin{tabular}{|c|}
$(6)$ \\
$\ln$ (housing stock) \\
2000
\end{tabular}} \\
\hline & \multicolumn{4}{|c|}{$\ln$ (total single family permits) } & & \\
\hline & $1980-2002$ & 1980-1989 & 1990-1999 & $1980-2002$ & & \\
\hline Acres per Lot & $\begin{array}{c}-0.547 \\
(0.133)^{* * *}\end{array}$ & $\begin{array}{c}-0.509 \\
(0.145)^{* * *}\end{array}$ & $\begin{array}{c}-0.685 \\
(0.165)^{* * *}\end{array}$ & $\begin{array}{c}-0.415 \\
(0.143)^{* * *}\end{array}$ & $\begin{array}{c}-0.442 \\
(0.133)^{* * *}\end{array}$ & $\begin{array}{c}-0.337 \\
(0.091)^{* * *}\end{array}$ \\
\hline $\ln$ (Townarea) & $\begin{array}{c}1.109 \\
(0.085)^{* * * *}\end{array}$ & $\begin{array}{c}1.03 \\
(0.096)^{* * *}\end{array}$ & $\begin{array}{c}1.307 \\
(0.098)^{* * *}\end{array}$ & $\begin{array}{c}0.816 \\
(0.100)^{* * *}\end{array}$ & $\begin{array}{c}0.892 \\
(0.078)^{* * *}\end{array}$ & $\begin{array}{c}0.45 \\
(0.043)^{* * *}\end{array}$ \\
\hline Distance to Boston & $\begin{array}{c}0 \\
(0.004)\end{array}$ & $\begin{array}{l}-0.001 \\
(0.004)\end{array}$ & $\begin{array}{l}-0.002 \\
(0.005)\end{array}$ & $\begin{array}{c}0.008 \\
(0.004)^{* *}\end{array}$ & $\begin{array}{c}-0.007 \\
(0.004)^{*}\end{array}$ & $\begin{array}{c}-0.015 \\
(0.003)^{* * *}\end{array}$ \\
\hline $\ln$ (Housing Stock) & $\begin{array}{c}0.063 \\
(0.050)\end{array}$ & $\begin{array}{c}0.119 \\
(0.054)^{* *}\end{array}$ & $\begin{array}{l}-0.031 \\
-0.06\end{array}$ & $\begin{array}{c}0.349 \\
(0.081)^{* * *}\end{array}$ & $\begin{array}{c}0.226 \\
(0.049)^{* * *}\end{array}$ & $\begin{array}{c}0.496 \\
(0.037)^{* * *}\end{array}$ \\
\hline Major University & $\begin{array}{l}-0.255 \\
-0.173\end{array}$ & $\begin{array}{l}-0.143 \\
(0.193)\end{array}$ & $\begin{array}{c}-0.692 \\
(0.316)^{* *}\end{array}$ & $\begin{array}{c}0.018 \\
(0.223)\end{array}$ & $\begin{array}{l}-0.227 \\
-0.151\end{array}$ & $\begin{array}{c}0.001 \\
(0.074)\end{array}$ \\
\hline Pct $<18$ years old & $\begin{array}{c}0.018 \\
(0.013)\end{array}$ & $\begin{array}{c}0.02 \\
(0.015)\end{array}$ & $\begin{array}{c}0.015 \\
(0.016)\end{array}$ & $\begin{array}{c}0.051 \\
(0.012)^{* * *}\end{array}$ & $\begin{array}{c}0.025 \\
(0.011)^{* *}\end{array}$ & $\begin{array}{c}0.015 \\
(0.009)^{*}\end{array}$ \\
\hline Pct. Foreign Born & $\begin{array}{c}0.011 \\
(0.011)\end{array}$ & $\begin{array}{c}0.021 \\
(0.012)^{*}\end{array}$ & $\begin{array}{l}-0.005 \\
-0.012\end{array}$ & $\begin{array}{l}-0.011 \\
(0.017)\end{array}$ & $\begin{array}{c}0.027 \\
(0.009)^{* * *}\end{array}$ & $\begin{array}{c}0.02 \\
(0.007)^{* * *}\end{array}$ \\
\hline Pct. White & $\begin{array}{c}0.018 \\
(0.009)^{* *}\end{array}$ & $\begin{array}{l}(0.003) \\
(0.009)\end{array}$ & $\begin{array}{c}0.043 \\
(0.013)^{* * *}\end{array}$ & $\begin{array}{c}0.015 \\
(0.014)\end{array}$ & $\begin{array}{c}0.006 \\
(0.008)\end{array}$ & $\begin{array}{c}-0.019 \\
(0.008)^{* *}\end{array}$ \\
\hline Constant & $\begin{array}{c}-5.744 \\
(1.222)^{* * *}\end{array}$ & $\begin{array}{c}-4.307 \\
(1.331)^{* * *}\end{array}$ & $\begin{array}{c}-9.79 \\
(1.638)^{* * *}\end{array}$ & $\begin{array}{c}-6.337 \\
(1.587)^{* * *}\end{array}$ & $\begin{array}{c}-3.74 \\
(1.128)^{* * *}\end{array}$ & $\begin{array}{c}2.729 \\
(0.957)^{* * *}\end{array}$ \\
\hline Controls Year & 1940 & 1940 & 1940 & 1980 & 1940 & 1940 \\
\hline \begin{tabular}{|l|} 
Observations \\
R-squared
\end{tabular} & $\begin{array}{l}185 \\
0.64\end{array}$ & $\begin{array}{l}185 \\
0.6\end{array}$ & $\begin{array}{l}185 \\
0.62\end{array}$ & $\begin{array}{l}185 \\
0.68\end{array}$ & $\begin{array}{l}185 \\
0.65\end{array}$ & $\begin{array}{l}186 \\
0.9\end{array}$ \\
\hline
\end{tabular}

Notes:

1. Robust standard errors in parentheses

2. * significant at $10 \%$; * significant at $5 \%$; *** significant at $1 \%$ 
Table 6 - Effect of Additional Zoning Policies on Annual Total Permits, 1980-2002

\begin{tabular}{|l|cc|cc|cc|}
\hline & $(1)$ & $(2)$ & $(3)$ & $(4)$ & $(5)$ & $(6)$ \\
\cline { 2 - 7 } & \multicolumn{2}{|c|}{$\ln$ (total permits) } & $\ln$ (total permits) & ln(total permits) \\
\hline \hline Wetlands Bylaw & -0.036 & -0.071 & & & & \\
Septic Rule & $(0.071)$ & $(0.084)$ & & & & \\
Subdivision Rule & 0.009 & -0.019 & & & & \\
& $(0.094)$ & $(0.103)$ & & & & \\
Regulation Index -- & -0.116 & -0.226 & & & & \\
Barrier & $(0.090)$ & $(0.097)^{* *}$ & & & & \\
& & & & & & \\
Cluster & & & -0.057 & -0.105 & -0.058 & -0.14 \\
& & & $(0.047)$ & $(0.053)^{* *}$ & $(0.060)$ & $(0.068)^{* *}$ \\
Inclusionary & & & & & 0.211 & 0.114 \\
& & & & & $(0.100)^{* *}$ & $(0.107)$ \\
Town Controls & & & & & 0.2 & 0.045 \\
Town FE & Yes & No & Yes & No & Yes & No \\
Year FE & No & Yes & No & Yes & No & Yes \\
& Yes & Yes & Yes & Yes & Yes & Yes \\
& 2507 & 2507 & 2507 & 2507 & 1732 & 1755 \\
& 0.49 & 0.63 & 0.49 & 0.63 & 0.51 & 0.65 \\
\hline
\end{tabular}

1. $*$ significant at $10 \% ; * *$ significant at $5 \% ; * * *$ significant at $1 \%$

2. Standard errors are clustered on town.

3. Dependant variable is $\ln$ (total permits) in each year for 1980-2002.

4. Town controls include minimum lot size, $\ln$ (townarea), $\ln$ (hsg 1970), major college dummy pct kids 1970, pct white 1970, pct BA+ 1970

5. Towns who adopt regulations at unknown dates are excluded. 
Table 7 - Effect of Minimum Lot Size and Additional Regulations on Sales Prices, 2000-2005

\begin{tabular}{|c|c|c|c|c|}
\hline & (1) & (2) & (3) & (4) \\
\hline & \multicolumn{4}{|c|}{$\ln ($ sales price, $\$ 2005)$} \\
\hline Acres per Lot & $\begin{array}{c}0.156 \\
(0.062)^{* *}\end{array}$ & $\begin{array}{l}-0.093 \\
(0.082)\end{array}$ & $\begin{array}{c}0.08 \\
(0.065)\end{array}$ & $\begin{array}{c}-0.093 \\
(0.079)\end{array}$ \\
\hline Total Regulation Index -- Barrier & & & $\begin{array}{c}0.101 \\
(0.034)^{* * *}\end{array}$ & $\begin{array}{c}0.071 \\
(0.032)^{* *}\end{array}$ \\
\hline Year Built & $\begin{array}{c}0.001 \\
(0.000)^{* * *}\end{array}$ & $\begin{array}{c}0.001 \\
(0.000)^{* * *}\end{array}$ & $\begin{array}{c}0.001 \\
(0.000)^{* * *}\end{array}$ & $\begin{array}{c}0.001 \\
(0.000)^{* * *}\end{array}$ \\
\hline $\ln ($ total number of rooms) & $\begin{array}{c}0.262 \\
(0.037)^{* * *}\end{array}$ & $\begin{array}{c}0.249 \\
(0.036)^{* * *}\end{array}$ & $\begin{array}{c}0.256 \\
(0.036)^{* * *}\end{array}$ & $\begin{array}{c}0.248 \\
(0.035)^{* * *}\end{array}$ \\
\hline $\ln$ (interior sq. ft.) & $\begin{array}{c}0.575 \\
(0.034)^{* * *}\end{array}$ & $\begin{array}{c}0.586 \\
(0.032)^{* * *}\end{array}$ & $\begin{array}{c}0.567 \\
(0.032)^{* * *}\end{array}$ & $\begin{array}{c}0.578 \\
(0.031)^{* * *}\end{array}$ \\
\hline $\ln ($ lot size $)$ & $\begin{array}{c}0.089 \\
(0.015)^{* * *}\end{array}$ & $\begin{array}{c}0.058 \\
(0.012)^{* * *}\end{array}$ & $\begin{array}{c}0.083 \\
(0.015)^{* * *}\end{array}$ & $\begin{array}{c}0.06 \\
(0.011)^{* * *}\end{array}$ \\
\hline $\ln ($ townarea $)$ & $\begin{array}{c}-0.076 \\
(0.051)\end{array}$ & $\begin{array}{c}0.002 \\
(0.050)\end{array}$ & $\begin{array}{c}-0.107 \\
(0.046)^{* *}\end{array}$ & $\begin{array}{c}-0.037 \\
(0.051)\end{array}$ \\
\hline Distance to Boston & $\begin{array}{c}-0.016 \\
(0.005)^{* * *}\end{array}$ & $\begin{array}{c}-0.019 \\
(0.004)^{* * *}\end{array}$ & $\begin{array}{c}-0.017 \\
(0.004)^{* * *}\end{array}$ & $\begin{array}{c}-0.019 \\
(0.004)^{* * *}\end{array}$ \\
\hline Major University & $\begin{array}{c}0.423 \\
(0.096)^{* * *}\end{array}$ & $\begin{array}{c}0.455 \\
(0.093)^{* * *}\end{array}$ & $\begin{array}{c}0.429 \\
(0.075)^{* * *}\end{array}$ & $\begin{array}{c}0.452 \\
(0.081)^{* * *}\end{array}$ \\
\hline Pct $<18$ years old 1940 & $\begin{array}{c}-0.019 \\
(0.008)^{* *}\end{array}$ & $\begin{array}{c}-0.028 \\
(0.008)^{* * *}\end{array}$ & $\begin{array}{c}-0.022 \\
(0.008)^{* * *}\end{array}$ & $\begin{array}{c}-0.028 \\
(0.008)^{* * *}\end{array}$ \\
\hline Pct. White 1940 & $\begin{array}{c}-0.001 \\
(0.015)\end{array}$ & $\begin{array}{c}0.003 \\
(0.016)\end{array}$ & $\begin{array}{c}0.003 \\
(0.015)\end{array}$ & $\begin{array}{c}0.005 \\
(0.016)\end{array}$ \\
\hline Pct. Mfg. 1940 & $\begin{array}{l}-0.089 \\
(0.124)\end{array}$ & $\begin{array}{l}-0.094 \\
(0.109)\end{array}$ & $\begin{array}{l}-0.118 \\
(0.114)\end{array}$ & $\begin{array}{l}-0.113 \\
(0.106)\end{array}$ \\
\hline $\ln$ (Housing Stock1940) & & $\begin{array}{c}-0.11 \\
(0.027)^{* * *}\end{array}$ & & $\begin{array}{c}-0.086 \\
(0.026)^{* * *}\end{array}$ \\
\hline Constant & $\begin{array}{c}5.986 \\
(1.692)^{* * *}\end{array}$ & $\begin{array}{c}6.619 \\
(1.687)^{* * *}\end{array}$ & $\begin{array}{c}5.806 \\
(1.706)^{* * *}\end{array}$ & $\begin{array}{c}6.355 \\
(1.697)^{* * *}\end{array}$ \\
\hline Year FE & YES & YES & YES & YES \\
\hline Observations & 55006 & 55006 & 55006 & 55006 \\
\hline R-squared & 0.31 & 0.32 & 0.32 & 0.33 \\
\hline
\end{tabular}

Notes:

1. Standard errors clustered by town.

2. * significant at $10 \% ; * *$ significant at $5 \% ; * * *$ significant at $1 \%$

3. Excludes towns $>30$ miles from Boston. 
Table 8 - Effect of Density on Sales Prices, 2000-2005

\begin{tabular}{|c|c|c|c|c|c|c|}
\hline & $(1)$ & $(2)$ & (3) & $(4)$ & (5) & (6) \\
\hline & \multicolumn{6}{|c|}{$\ln ($ sales price $\$ 2005)$} \\
\hline \multirow[t]{2}{*}{ In(housing density 2000) } & -0.083 & -0.05 & 0.054 & -0.126 & -0.114 & -0.148 \\
\hline & $(0.033)^{\star *}$ & $(0.042)$ & $(0.081)$ & $(0.034)^{* * *}$ & $(0.033)^{\star \star *}$ & $(0.034)^{\star \star \star}$ \\
\hline \multirow[t]{2}{*}{$\ln ($ lot size $)$} & 0.06 & 0.069 & 0.126 & 0.038 & & \\
\hline & $(0.013)^{\star * *}$ & $(0.016)^{\star \star \star}$ & $(0.032)^{\star * *}$ & $(0.013)^{\star \star *}$ & & \\
\hline \multirow[t]{2}{*}{ Year built } & 0.001 & 0.001 & 0.001 & 0.001 & 0.001 & 0.001 \\
\hline & $(0.000)^{\star * *}$ & $(0.000)^{\star \star \star}$ & $(0.000)^{\star * *}$ & $(0.000)^{* * *}$ & $(0.000)^{* \star *}$ & $(0.000)^{\star \star \star}$ \\
\hline \multirow[t]{2}{*}{ In(total number of rooms) } & 0.256 & 0.26 & 0.244 & 0.258 & 0.273 & 0.269 \\
\hline & $(0.041)^{* * *}$ & $(0.042)^{\star \star \star}$ & $(0.045)^{* * *}$ & $(0.042)^{* * *}$ & $(0.043)^{* \star *}$ & $(0.044)^{\star * *}$ \\
\hline \multirow[t]{2}{*}{ In(interior sq. ft) } & 0.604 & 0.608 & 0.594 & 0.608 & 0.642 & 0.632 \\
\hline & $(0.042)^{\star \star *}$ & $(0.041)^{\star * *}$ & $(0.038)^{* * *}$ & $(0.043)^{* * *}$ & $(0.038)^{\star * *}$ & $(0.039)^{\star * *}$ \\
\hline \multirow[t]{2}{*}{ Distance to Boston } & -0.021 & -0.018 & -0.014 & -0.023 & -0.02 & -0.023 \\
\hline & $(0.004)^{* * *}$ & $(0.005)^{\star \star \star}$ & $(0.006)^{\star *}$ & $(0.004)^{* * *}$ & $(0.004)^{* * *}$ & $(0.004)^{* * *}$ \\
\hline \multirow[t]{2}{*}{ Major university } & 0.408 & 0.396 & 0.375 & 0.419 & 0.401 & 0.416 \\
\hline & $(0.100)^{\star \star \star}$ & $(0.100)^{\star * *}$ & $(0.106)^{\star * *}$ & $(0.099)^{* * *}$ & $(0.101)^{\star \star \star}$ & $(0.099)^{* * *}$ \\
\hline \multirow[t]{2}{*}{ Year } & 0.088 & 0.087 & 0.087 & 0.088 & 0.088 & 0.088 \\
\hline & $(0.002)^{* * *}$ & $(0.002)^{\star \star \star}$ & $(0.002)^{\star * *}$ & $(0.002)^{* * *}$ & $(0.002)^{* \star *}$ & $(0.002)^{* * *}$ \\
\hline \multirow[t]{2}{*}{ Constant } & -170.159 & -169.317 & -169.899 & -170.161 & -170.817 & -170.578 \\
\hline & $(4.841)^{\star * *}$ & $(4.884)^{\star * \star}$ & $(4.940)^{\star * *}$ & $(4.820)^{\star * *}$ & $(4.823)^{\star \star *}$ & $(4.811)^{\star \star *}$ \\
\hline & & Avg. min. lot & Forest acres & In(housing & & In(housing \\
\hline 2000) & None & size & 1885 & $\begin{array}{c}\text { density } \\
\text { 1915) }\end{array}$ & None & $\begin{array}{c}\text { density } \\
1915)\end{array}$ \\
\hline 1st stage F-stat & & 112.44 & 21.41 & 186.84 & & 261.06 \\
\hline Observations & 56105 & 55200 & 55349 & 56105 & 56107 & 56107 \\
\hline R-squared & 0.31 & 0.31 & 0.3 & 0.31 & 0.31 & 0.31 \\
\hline
\end{tabular}

Notes:

1. Standard errors clustered on town in parentheses

2. * significant at $10 \%$; ${ }^{* *}$ significant at $5 \%$; ${ }^{* * *}$ significant at $1 \%$

3. Excludes towns greater than 30 miles from Boston. 
Figure 1 - Total Permits in Boston Metro-Area, 1961-2002

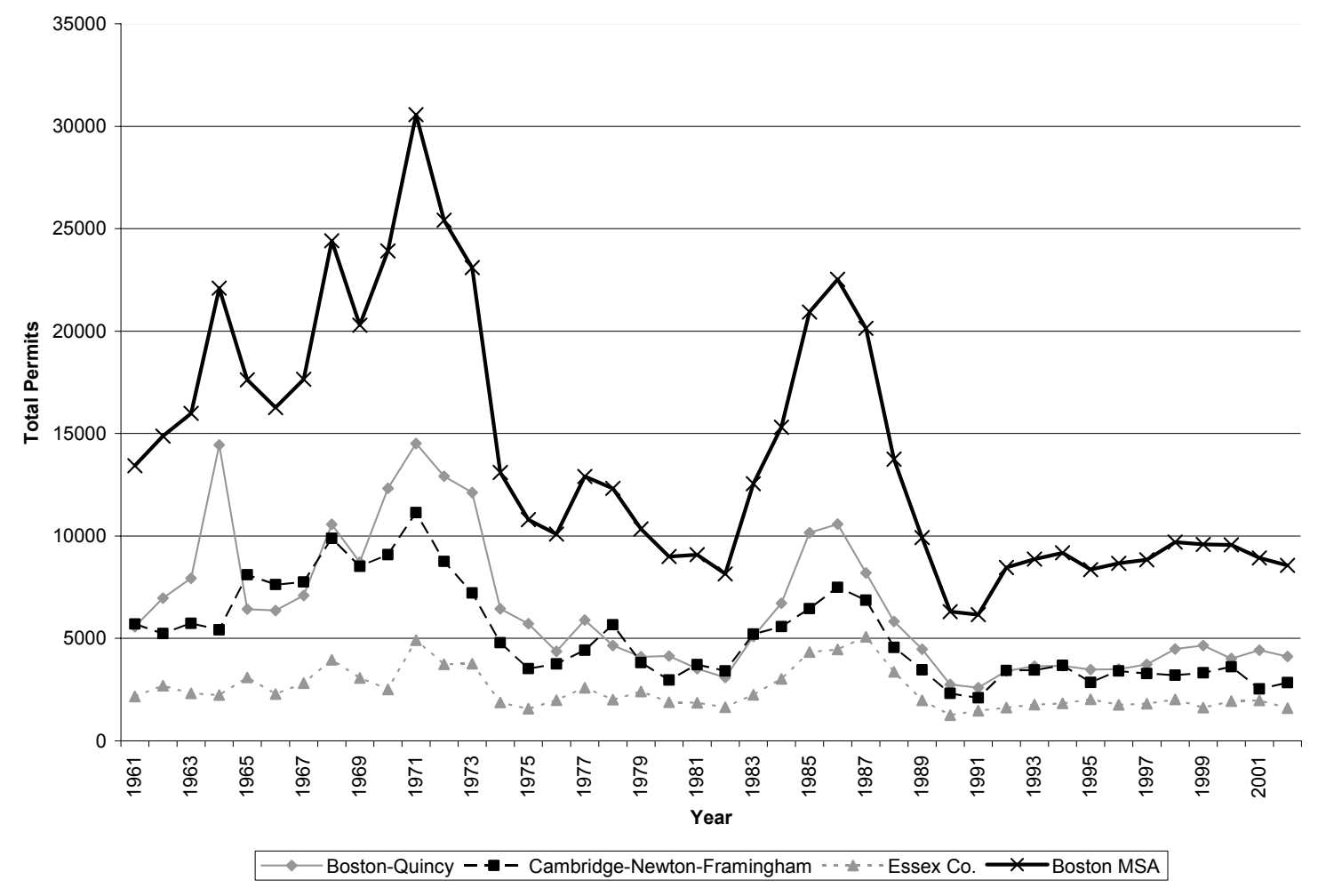


Figure 2 - Relationship between Total Permits 1980-2002 per Acre and 1980 Housing Density

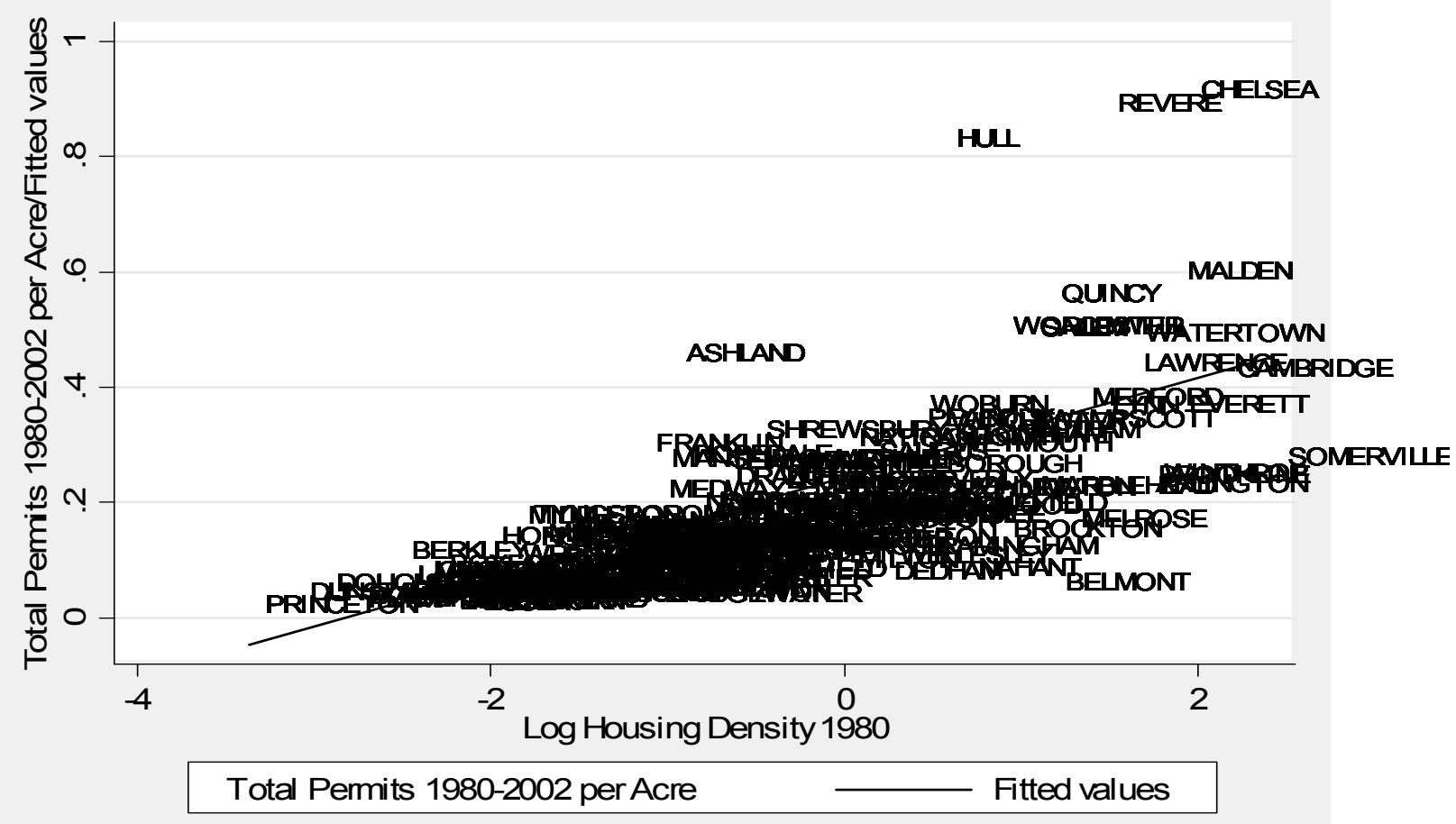


Figure 3 - Relationship between Minimum Lot Size and Forested Area 1885

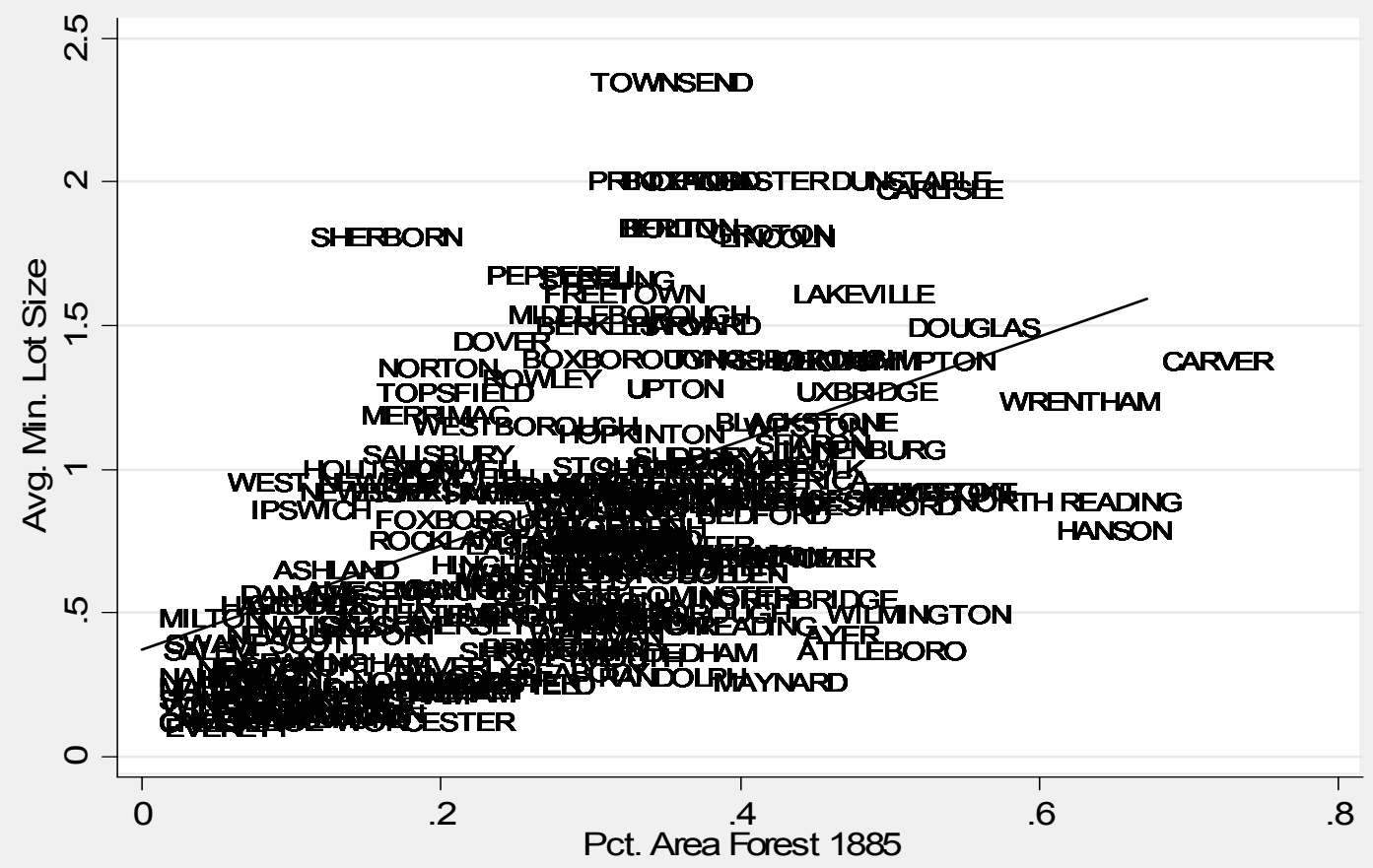

Source: MassGIS, Harvard Forest Archive. 
Figure 4: Frequency of restrictions greater than Title $\mathrm{V}$ requirements

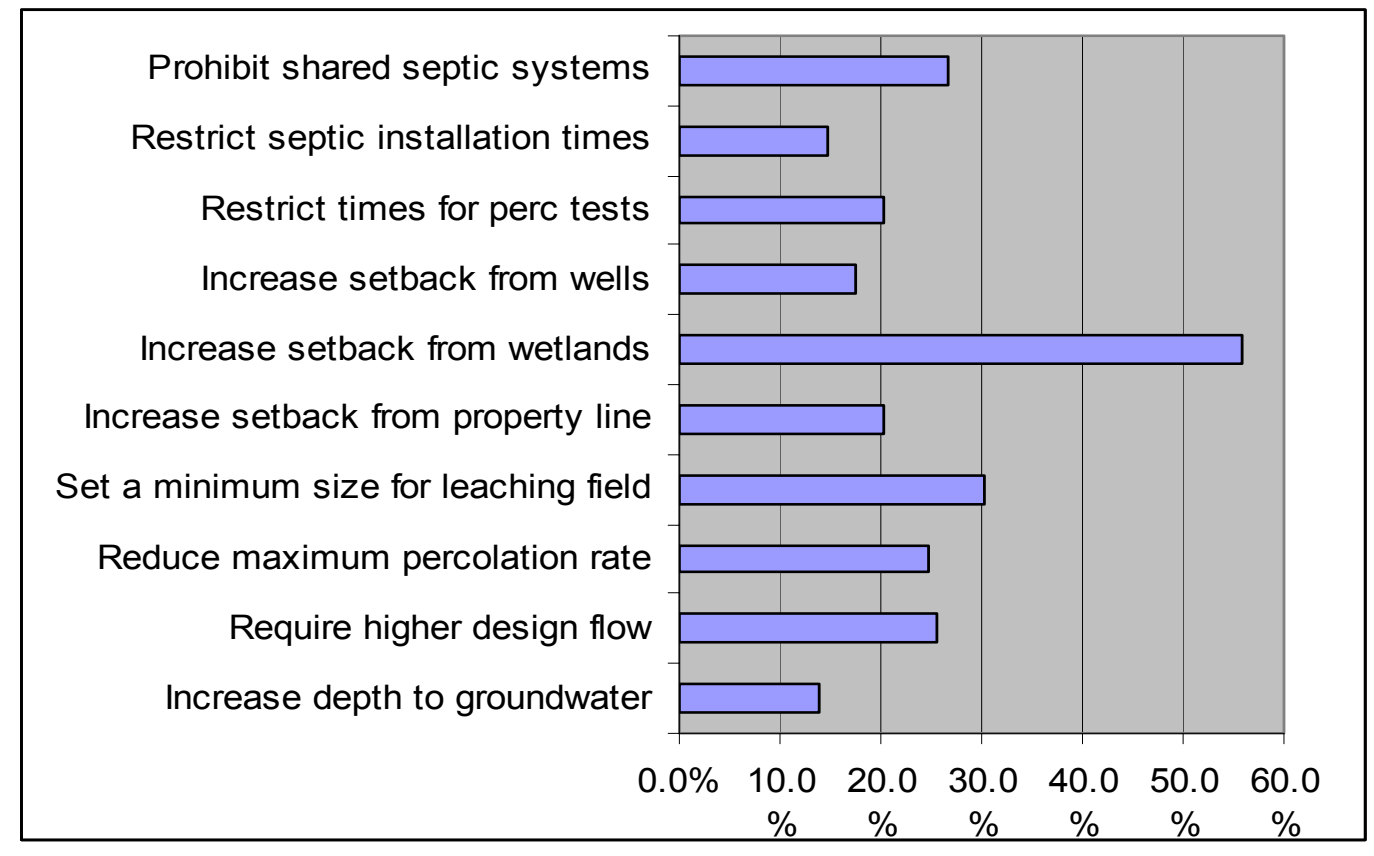


Figure 5 - Fraction of Communities with Wetlands, Septic, Subdivision, and Cluster Provisions, 1975-2004

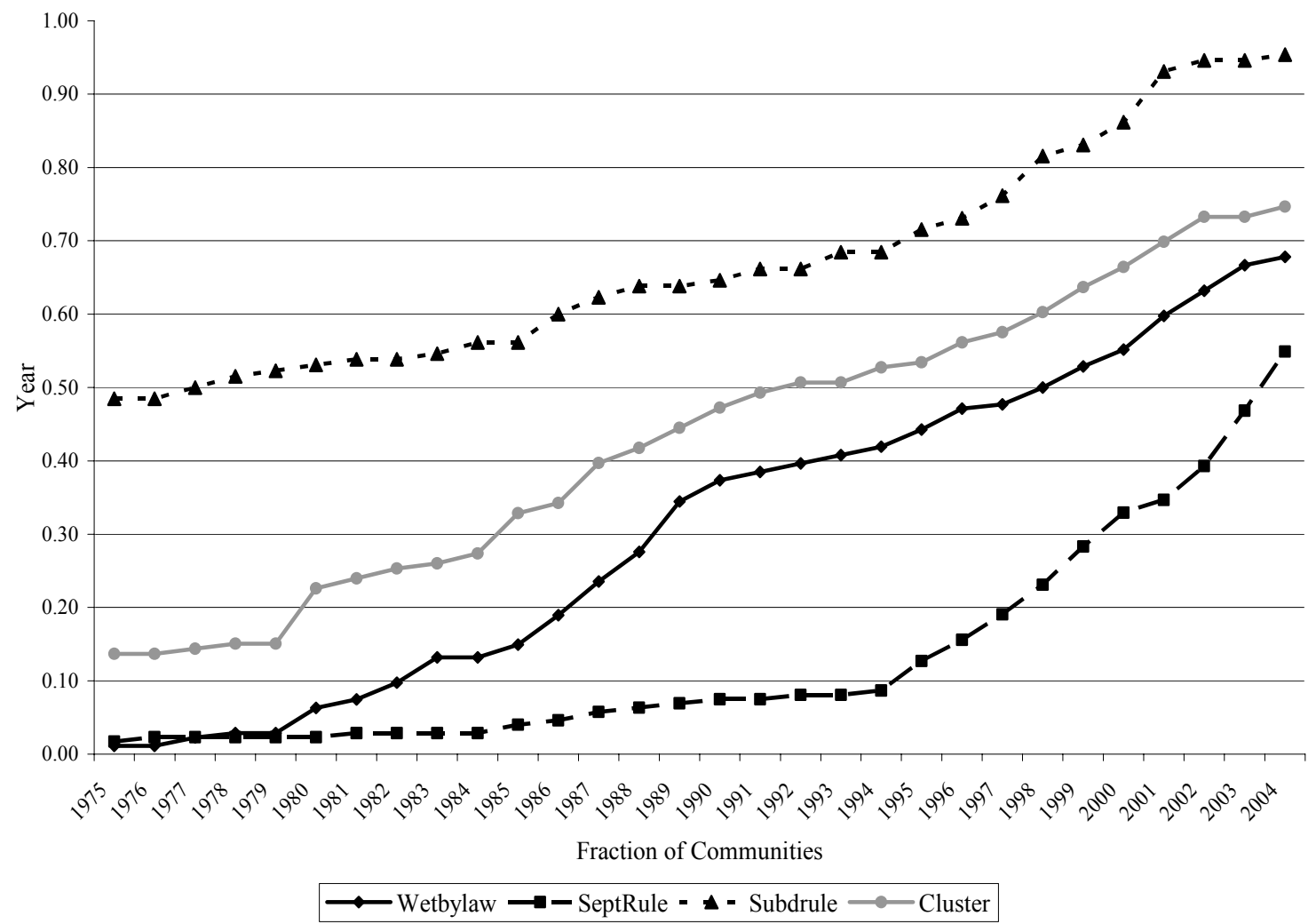

Notes -- Communities who adopt provisions at unknown dates are excluded from fraction. 
Figure 6 - Number of Communities Amending Wetlands Bylaws, Subdivision Rules, and Cluster Provisions, 1984-2004

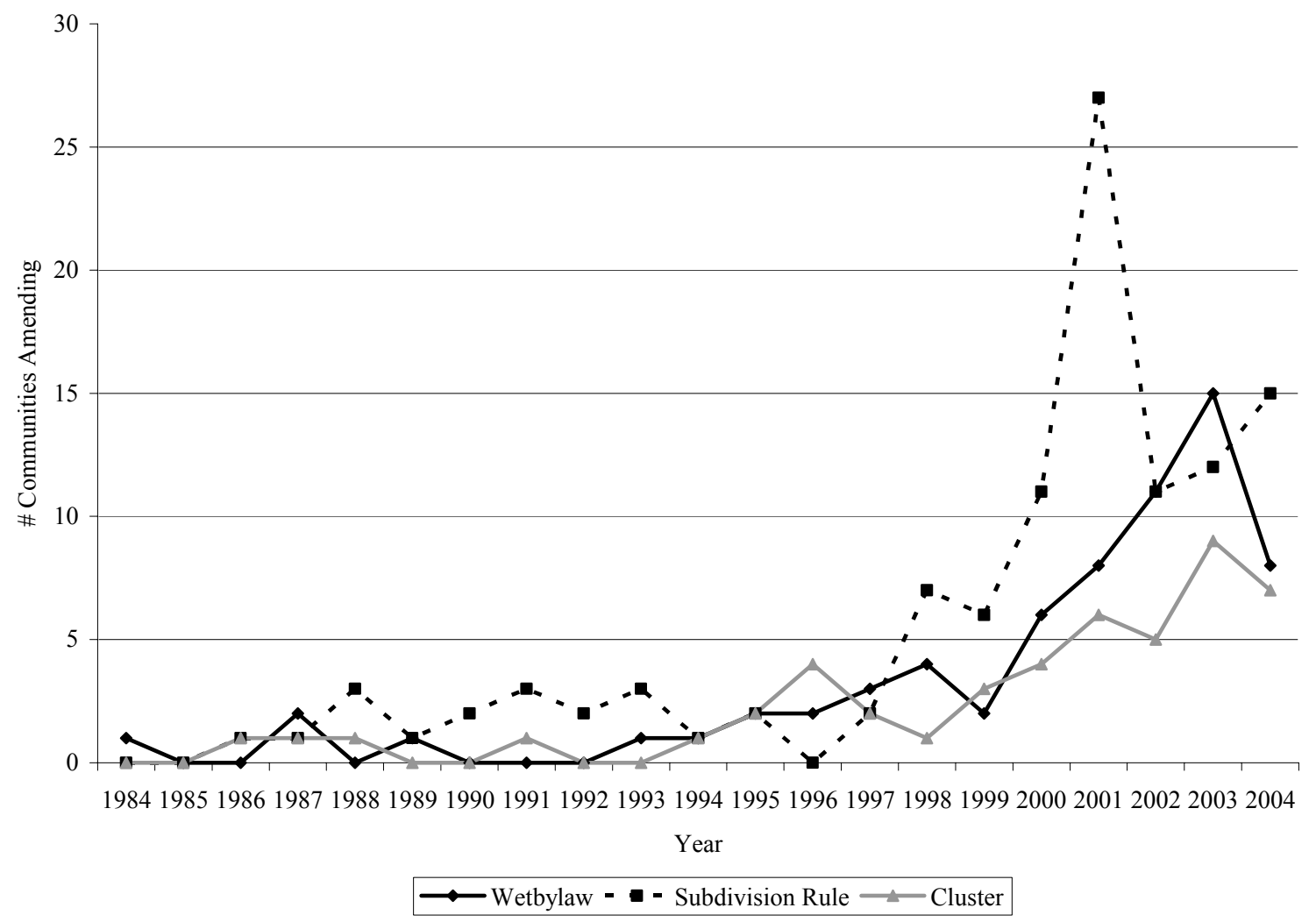


Figure 7 - Massachusetts Court Decisions Containing Key Words: Zoning, Residential and (Septic or Wetland), 1964-2004

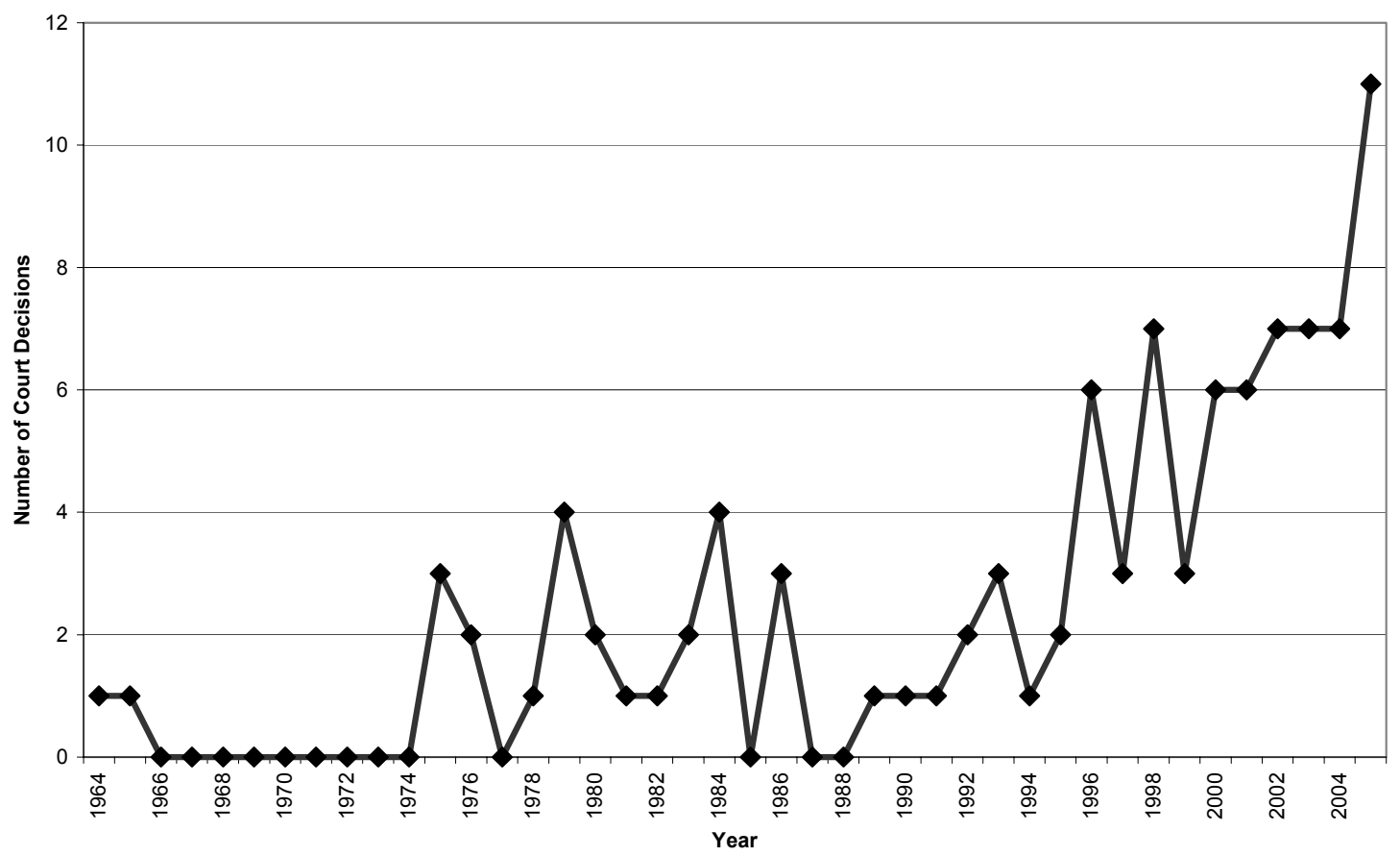

Source: Lexis-Nexis 